\begin{tabular}{lccc} 
& GOSPODARKA & SUROWCAMI & MINERALNYMI \\
\hline Tom 28 & 2012 & Zeszyt 3 \\
& DOI 10.2478/v10269-012-0022-2 &
\end{tabular}

\title{
Analiza mechaniki procesu rozdrabniania surowców mineralnych w kruszarkach i wysokociśnieniowych prasach walcowych
}

\begin{abstract}
Wprowadzenie
Proces rozdrabniania skał wywołany jest przez naprężenia wewnętrzne, których wielkość przekracza wartości graniczne. Naprężenia wewnętrzne są pochodną oddziaływań kruszących, takich jak ściskanie, udar, zginanie, ścinanie itp. Wynik rozdrabniania w konkretnej kruszarce jest uzależniony od właściwości wytrzymałościowych ziaren danego surowca, a także od charakteru oddziaływań kruszących. W każdej kruszarce występuje wiele oddziaływań kruszących, z których jedno, zależnie od typu kruszarki, ma znaczenie dominujące. W kruszarkach udarowych czy młotkowych dominujące znaczenie posiada udar. W kruszarkach szczękowych, stożkowych, walcowych i prasach walcowych występuje głównie ściskanie, ale także ścinanie i zginanie. Dlatego korzystne jest wielorakie oddziaływanie elementów kruszarek na rozdrabniany materiał. Stąd na przykład ważny jest kształt powierzchni szczęk kruszarek szczękowych, ukształtowanie powierzchni stożków kruszarek stożkowych, ukształtowanie powierzchni walców kruszarek i pras walcowych.

Charakter i wielkość odkształceń zależy od typu i wielkości przyłożonych sił (naprężeń), dlatego skały charakteryzują się różną wytrzymałością, zależnie od sposobu przyłożenia obciążenia. Orientacyjne zależności pomiędzy wytrzymałością na ściskanie $R_{c}$, zginanie $R_{g}$, ścinanie $R_{t}$ i rozciaganie $R_{r}$, przedstawiają się następująco (Majcherczyk 1989):

* Prof. dr hab., AGH Akademia Górniczo-Hutnicza, Wydział Górnictwa i Geoinżynierii, Kraków; e-mail: brozek@agh.edu.pl

** Dr inż., Instytut Ceramiki i Materiałów Budowlanych, Oddział Szkła i Materiałów Budowlanych, Kraków; e-mail: z.naziemiec@icimb.pl
\end{abstract}




$$
\begin{aligned}
& -R_{r}=0,013-0,05 R_{c} \\
& -R_{g}=0,067-0,2 R_{c} \\
& -R_{t}=0,067-0,2 R_{c} .
\end{aligned}
$$

\section{Opis mechaniki procesów kruszenia}

W opisie mechaniki procesów kruszenia znajdują zastosowanie różne teorie i hipotezy, np. teoria stanów granicznych, teoria sprężystości, teoria plastyczności. Teoria stanów granicznych pozwala na rozwiązywanie takich problemów mechaniki kruszenia, jak określenie sił kruszenia, mechanizmów pękania i mocy dyssypowanej w różnych procesach. Pojęcie stanów granicznych jest umowne, a najogólniej można go zdefiniować jako stan, który powoduje niezdolność do przenoszenia przez materiał (np. skałę o właściwościach kruchych) dodatkowych obciążeń. Warunki stanu granicznego pozwalają przewidywać krytyczny stan naprężenia, który powoduje, że w izotropowym ośrodku rozpoczyna się proces pękania z towarzyszącym mu malejącym obciążeniem bądź rozwój odkształceń plastycznych. Warunki te są tylko hipotezami, gdyż nie znamy sposobu ich teoretycznego wyprowadzenia. Stopień przydatności takich hipotez można sprawdzić, opierając się jedynie na wynikach doświadczeń nad zachowaniem się materiałów w prostych i złożonych stanach naprężeń (Zawada 1986).

Omawiając różne stany naprężeń należy stwierdzić, że podstawowe znaczenie posiada tutaj budowa i właściwości wytrzymałościowe materiałów kruchych oraz sposób obciążenia materiału. Wyszczególnić możemy obciążenia jednokierunkowe, dwukierunkowe, trójkierunkowe i obciążenia cykliczne. Przykładem jednokierunkowego obciążenia może być próba jednoosiowego ściskania, jednoosiowego rozciągania, zginania czy ścinania. W efekcie dochodzi wówczas do prostego lub złożonego stanu naprężenia i złożonego stanu odkształcenia (Zawada 1986).

Trudności w badaniach wytrzymałości materiałów kruchych na bezpośrednie rozrywanie spowodowały, że w praktyce są stosowane zwykle metody przybliżone. Doświadczenie wykazuje, że wartości naprężeń krytycznych - prowadzących do zniszczenia ziarna uzyskane metodą ściskania nie odbiegają od uzyskiwanych metodą udarową (Shipway, Hutchings 1993). Ze względu na to, że badanie skał metodą ściskania jest łatwiejsze, do oceny właściwości surowców często stosuje się tę metodę (Brożek, Oruba-Brożek 2003).

W teorii sprężystości właściwości wytrzymałościowe skał określają charakterystyki mechaniczne, np. w próbach rozciągania i ściskania charakterystyki $\sigma-\varepsilon$ (gdzie $\sigma-\mathrm{są}$ naprężeniami normalnymi działającymi w przekrojach prostopadłych do kierunku działania obciążeń, $\varepsilon$ zaś skróceniem lub wydłużeniem względnym w kierunku działania obciążeń). Pomiędzy naprężeniami a odkształceniami istnieje ścisła zależność. W zakresie odkształceń sprężystych zależność tą określa prawo Hooke’a, które wyraża związek pomiędzy naprężeniami w przekroju poprzecznym próbki a jej wydłużeniem właściwym. Jest to funkcja liniowa w postaci: 
gdzie:

$\sigma$ - naprężenie w próbce $\left[\mathrm{N} / \mathrm{m}^{2}\right]$,

$E$ - moduł sprężystości (moduł Younga) $\left[\mathrm{N} / \mathrm{m}^{2}\right]$,

$\varepsilon$ - wydłużenie właściwe $\Delta l / l$ (odkształcenie względne).

Najbardziej rozpowszechnione jest poprzeczne ściskanie cienkich tarcz (walców) obciążeniem rozłożonym na niewielkiej powierzchni. Badanie to jest powszechnie znane pod nazwą próby brazylijskiej. Test brazylijski polega na osiowym ściskaniu dysku o średnicy $d$ i grubości $h$. W środku dysku powstają naprężenia rozrywające, które prowadzą do zniszczenia próbki. Porównanie wytrzymałości dysku i nieregularnych ziaren ściskanych między dwoma punktami wykazało, że są sobie równe (Broch, Franklin 1972).

Przy pomiarach wytrzymałości ziaren mineralnych na rozrywanie obserwuje się duży rozrzut wyników. Rozrzut ten jest spowodowany losowością zjawisk zachodzących w trakcie rozrywania, takich jak kształt ziarna, ułożenie ziarna, warunki obciążenia oraz wewnętrzna struktura konkretnego ziarna. Z tego względu wytrzymałość materiału skalnego charakteryzuje się pewnym rozkładem, a proces rozdrabniania ma charakter statystyczny (Cotrell 1964).

Warto pamiętać, że powiększenie wilgotności skał powoduje obniżenie ich wytrzymałości ponieważ woda jest związkiem powierzchniowo czynnym obniżającym swobodną energię powierzchniową (Brożek i in. 2008). Dla skał zwięzłych zmniejszenie wytrzymałości na ściskanie przy nasyceniu wodą kształtuje się w granicach $10-30 \%$, a niekiedy nawet więcej (Hobler 1977). Jest to bardzo istotne w procesach rozdrabniania surowców skalnych, które prowadzone są najczęściej w stanie wilgotności naturalnej.

W teorii plastyczności przyjmuje się, że o zniszczeniu ciała decydują naprężenia tnące. Określenie wytrzymałości na ścinanie dla skał spoistych sprowadza się do określenia kąta tarcia wewnętrznego $\varphi$ i wielkości siły spójności $c$, przy określonej wilgotności. Skały spoiste przeciwstawiają się ścięciu dzięki tarciu wewnętrznemu i dzięki sile spójności. Tarcie wewnętrzne jest to mechaniczny opór ziaren lub cząstek skały przeciw przesuwaniu się względem siebie. Opór spójności spowodowany jest istnieniem sił molekularnego przyciągania, sił wodno-koloidalnych i sił kapilarnych. Dla skał spoistych zależność pomiędzy wytrzymałością na ścinanie a tarciem wewnętrznym i spójnością określa wzór Culomba:

$$
\tau=\sigma_{n} \operatorname{tg} \varphi+c
$$

gdzie:

$\tau$ - wytrzymałość na ścinanie (graniczne naprężenie ścinające) $\left[\mathrm{N} / \mathrm{m}^{2}\right]$,

$\sigma_{n}$ - naprężenie normalne do powierzchni ścięcia $\left[\mathrm{N} / \mathrm{m}^{2}\right]$,

$\varphi$ - kąt tarcia wewnętrznego,

$c-$ spójność $\left[\mathrm{N} / \mathrm{m}^{2}\right]$. 
Wyniki badań trójosiowego ściskania uzupełnione wynikami badań przy obciążeniach jednokierunkowych, stanowią podstawę wyznaczenia tzw. krzywej granicznej (obwiedni stanu granicznego), mającej w mechanice kruszenia podstawowe znaczenie. Krzywa graniczna jest obwiednią kół Mohra wykreślonych dla różnych wartości ciśnień hydrostatycznych i odpowiadającym im wartości naprężeń $\sigma$. Krzywa jest wykreślona w układzie współrzędnych $\tau-\sigma$, gdzie $\tau$ oznacza naprężenia styczne, a $\sigma$ naprężenia normalne działające w określonych płaszczyznach próbki. Punkty na krzywej granicznej określają graniczne naprężenia normalne i styczne działające w płaszczyznach poślizgu powstających w trakcie procesu pękania czy też plastycznych deformacji materiału. Przykład krzywej granicznej dla wapienia zwartego przedstawiono na rysunku 1 (Zawada 1986).

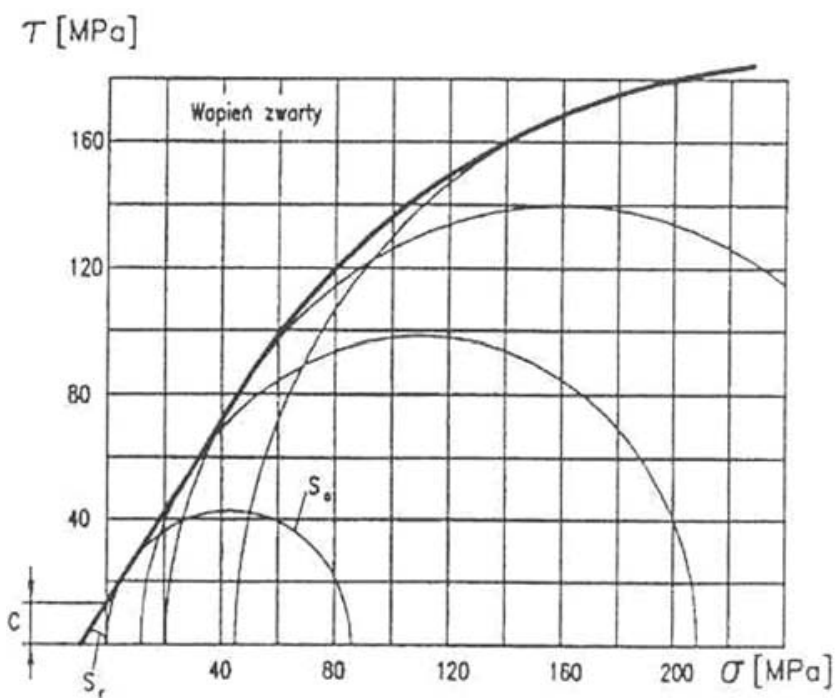

Rys. 1. Krzywa graniczna $\tau=f(\sigma)$ dla wapienia zwartego

$S_{c}$ i $S_{r}$ - koła Mohra odpowiadające wytrzymałości na jednoosiowe ściskanie $\left(S_{c}\right)$ i rozrywanie $\left(S_{r}\right)$, $c$ - spójność materiału (Zawada 1986)

Fig. 1. Boundary curve $\tau=f(\sigma)$ for a compact limestone $S_{c}$ and $S_{r}-$ Mohr's circles corresponding with the resistance to single-axial pressure $\left(S_{c}\right)$ and tearing apart $\left(S_{r}\right)$, c - material consistence (Zawada 1986)

Krzywa graniczna jest obwiednią kół Mohra wykreślonych dla różnych wartości ciśnień hydrostatycznych $p=\sigma_{2}=\sigma_{3}$ i odpowiadającym im wartości pionowych naprężeń $\sigma_{1}$. Na rysunku $\tau$ oznacza naprężenia styczne, $\sigma$ zaś naprężenia normalne działające w określonych płaszczyznach próbki. Punkty na krzywej granicznej określają graniczne naprężenia styczne i graniczne naprężenia normalne, działające w płaszczyznach poślizgu powstających w trakcie procesu pękania czy też plastycznych deformacji materiału. 


\section{Proces rozdrabniania w wysokociśnieniowych prasach walcowych}

Opisane zagadnienia są istotne $\mathrm{w}$ analizie warunków rozdrabniania, jakie mają miejsce w kruszarkach i prasach walcowych. Wysokociśnieniowe prasy walcowe są współczesną odmianą kruszarek walcowych i znajdują coraz większe zastosowanie w procesach rozdrabniania surowców mineralnych. Stosowane bywają do rozdrabniania w procesach produkcji kruszyw drobnych, znajdujących zastosowanie jako różnego rodzaju wypełniacze czy sorbenty. Kruszeniu poddawane są wówczas wapienie lub dolomity. Z uwagi na niską energochłonność znajdują coraz szersze zastosowanie w przeróbce rud, jak również w przemyśle cementowym, w procesach przemiału klinkieru (Saramak 2011b; Saramak i in. 2010).

W kruszarkach i prasach walcowych rozdrabnianie następuje pomiędzy dwoma poziomymi walcami, obracającymi się ku sobie. Walce mogą być o powierzchni gładkiej, rowkowanej lub zębatej. Walce o odpowiednio ukształtowanej powierzchni (np. zębate) zapewniają lepszy uchwyt dużych kawałków kruszonego materiału. Jeden z walców obraca się w łożyskach nieruchomych, natomiast drugi w łożyskach ruchomych, dociskanych przez sprężyny. Taki sposób zamocowania umożliwia przesuwanie się walca w kierunku poziomym, a tym samym zabezpiecza je przed uszkodzeniem w przypadku przedostania się twardych przedmiotów oraz umożliwia regulację szerokości szczeliny wylotowej. Pomiędzy walcami występuje wielorakie oddziaływanie na rozdrabniany materiał. Gdy oba walce obracają się z jednakową prędkością rozdrabnianie następuje w wyniku zgniatania (przy walcach gładkich i rowkowanych) lub rozłupywania (przy walcach uzębionych). Gdy walce obracają się z różną prędkością obok zgniatania występuje ścieranie, a przy walcach uzębionych rozrywanie. Przy różnych prędkościach walców w mniejszym stopniu występuje zjawisko oblepiania walców wilgotnym materiałem ilastym. Przy rozdrabnianiu przez zgniatanie materiału między walcami, przy małym działaniu ścierającym, uzyskiwany produkt zawiera stosunkowo mało drobnych ziaren. Wpływ na małą zawartość frakcji drobnych w produktach pokruszonych ma również krótki czas przebywania materiału między walcami.

W prasie walcowej siła nacisku wywierana jest przez system hydrauliczny, który zwykle za pomocą czterech tłoków naciska na oś jednej z rolek (rolki przesuwnej) dociskając ją w kierunku drugiej, nieprzesuwnej rolki. Przemysłowe układy hydrauliczne w prasach walcowych zdolne są wywrzeć ciśnienie rzędu $200 \mathrm{MPa}$, co przekłada się na siły nacisku właściwego rzędu 4-5 $\mathrm{N} / \mathrm{mm}^{2}$. Najnowsze przemysłowe prasy walcowe są zdolne do uzyskiwania nacisków sięgających nawet do $300 \mathrm{MPa}$. Realne maksymalne ciśnienie panujące w ściskanej warstwie materiału można obliczyć stosując wzór (Naziemiec, Saramak 2009):

$$
R_{\max }=\frac{F_{s p}}{\pi \frac{\alpha}{360}}
$$


gdzie:

$R_{\max }-$ maksymalne ciśnienie w szczelinie pomiędzy walcami prasy [MPa],

$F_{s p} \quad-$ nacisk specyficzny w prasie $[\mathrm{MPa}]$,

$\alpha \quad-$ kąt strefy zgniotu [stopnie].

Oprócz innego źródła siły nacisku inny jest także sposób podawania nadawy do prasy walcowej. Materiał jest podawany w tzw. dławiennym systemie, polegającym na umieszczeniu bezpośrednio nad prasą zbiornika samowyładowczego. Materiał wypełnia całą przestrzeń bezpośrednio nad urządzeniem, a także samą komorę roboczą prasy. Materiał jest upakowany i dosyć istotnie zredukowane są powietrzne przestrzenie pomiędzy ziarnami w ten sposób, że mniejsze ziarna lokują się w przestrzeniach pomiędzy większymi ziarnami. Ułatwia to przesuwanie się materiału we wspomnianym zbiorniku samowyładowczym w dół oraz wstępne zagęszczanie warstwy materiału już w górnej części komory roboczej (rys. 2).

W wyniku procesu rozdrabniania powstają mikroszczeliny i mikropęknięcia w pojedynczych ziarnach, co ułatwia ich rozdrabnianie w dalszych etapach, głównie na trzecim lub czwartym stopniu rozdrabniania w młynach kulowych. Osiagana wartość energochłonności mierzona wskaźnikiem Bonda ulega redukcji o około 20-30\% w przypadku mniej twardych wapieni i $15-20 \%$ dla twardszych surowców.

Proces rozdrabniania $\mathrm{w}$ wysokociśnieniowych prasach walcowych jest determinowany różnymi czynnikami związanymi z samym urządzeniem, właściwościami nadawy oraz specyfiką całego technologicznego układu rozdrabniania (Saramak 2010, 2011a, 2011c). Cechą charakterystyczną pras walcowych jest także to, że pracują z zamkniętym obiegiem materiału (Saramak 2011b). Krotność obiegu najczęściej wynosi około 2, a niekiedy nawet więcej. Badania pras walcowych wykazały, że przeróbka materiału monofrakcyjnego

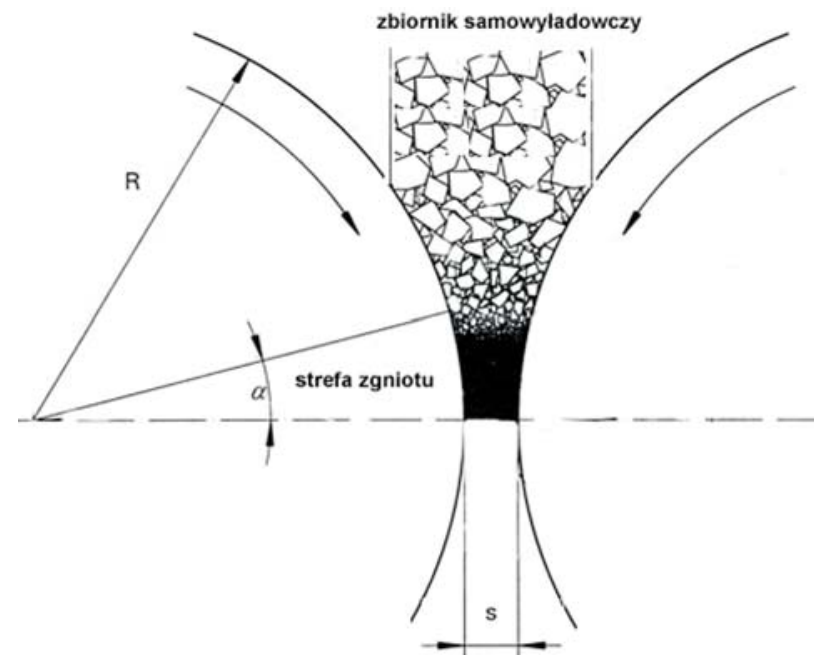

Rys. 2. Schemat rozdrabniania warstwy materiału w prasie walcowej

Fig. 2. A scheme of high-pressure comminution 
pozwala uzyskać wyższe stopnie rozdrobnienia (o ok. 30\%) niż przy rozdrabnianiu materiałów polifrakcyjnych, jednak wydajność prasy przy zgniataniu materiału monofrakcyjnego ulega znacznemu obniżeniu. Przyczyną jest pogorszenie się warunków zagęszczania i stabilizacji zgniatanej warstwy. Poprawę stopnia zagęszczenia można osiagnąć wprowadzając część materiału drobnego do materiału monofrakcyjnego. Sprzyja temu stosowany w praktyce zawrót części materiału podczas rozdrabniania w obiegu zamkniętym (Nowak 1999).

Z badań przeprowadzonych nad ściskaniem pojedynczych ziaren wapienia i porfiru wynika, że średnia wytrzymałość ziaren jest zależna od wielkości ziarna i rośnie ze zmniejszeniem się wymiaru ziarna (rys. 3) (Brożek, Oruba-Brożek 2003).

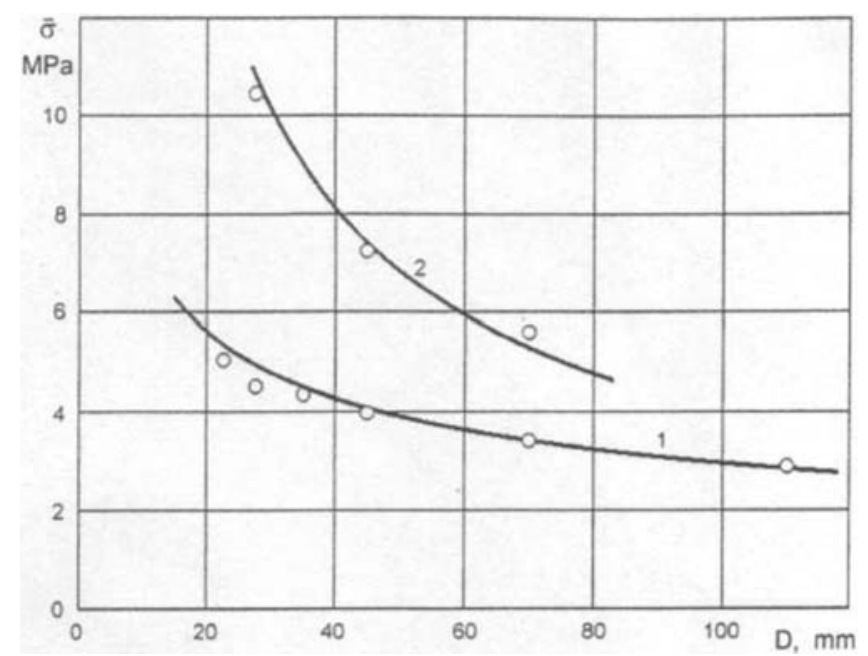

Rys. 3. Zależność średniej wytrzymałości ziaren $\sigma$ od wielkości ziarna $D$ : 1 - dla wapienia, 2 - dla porfiru (Brożek i Oruba-Brożek 2003)

Fig. 3. Relationship between an average particle's tensile strength $\sigma$ and the particle size $D$ : for limestone (1) and for porphyry (2) (Brożek and Oruba-Brożek 2003)

Losowy charakter wytrzymałości wynika z obecności mikroszczelin i wad, których ilość i wielkość są zmiennymi losowymi. W ciałach kruchych, do których należy większość surowców mineralnych, istnieją mikropęknięcia lub inne nieciągłości i wady struktury jak dyslokacje, defekty upakowania, mikropory, wpryśnięcia innych minerałów, wokół których następuje koncentracja naprężeń podczas rozciągania. W niektórych ciałach stałych pęknięcia moga powstać przez poślizg plastyczny. W przypadku rozdrabniania przez ściskanie ciał mechanicznie izotropowych, jakimi są surowce mineralne, szczeliny będą się rozwijać w pobliżu deformacji plastycznych. Najbardziej prawdopodobnym miejscem powstawania szczelin są warstwy powierzchniowe na granicy kontaktu rozdrabnianego ziarna ze ściskającym lub uderzającym przedmiotem (Brożek i in. 1995).

$\mathrm{Z}$ powyższego opisu wynika, że rozdrabnianie ziaren przeprowadzone w warunkach skrępowanych (rozdrabnianie warstwowe - rys. 4), powinno sprzyjać zwiększeniu kon- 
146

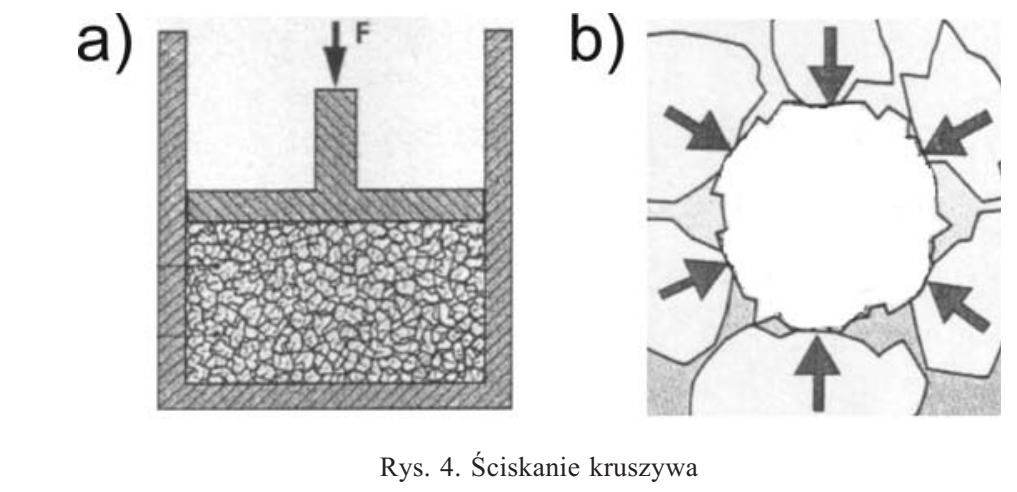

a) cylinder z kruszywem obciążanym stemplem prasy; b) ziarno ściskane w warstwie materiału

Fig. 4. Aggregates pressing tests

a) the piston-die test, b) particle under pressing forces in the material bed

centracji naprężeń i zachodzić przy użyciu mniejszej siły (mniejszego ciśnienia). Zarazem należy pamiętać, że ziarna drobne wypełniające puste przestrzenie pomiędzy ziarnami grubymi charakteryzują się większą wytrzymałością.

Jeżeli natomiast odniesiemy warunki panujące $\mathrm{w}$ ściskanej warstwie materiału do badania procesu ściskania $\mathrm{w}$ trójosiowym stanie naprężenia, możemy się spodziewać wzrostu wytrzymałości rozdrabnianego materiału. Stwierdzenie to wynika z analizy wielkości naprężeń przedstawionych za pomocą kół Mohra na rysunku 1.

Dla oceny przedstawionych wyżej hipotez w odniesieniu do rozdrabniania w wysokociśnieniowych prasach walcowych przeprowadzono badania eksperymentalne.

\section{Badania eksperymentalne}

Stopień przydatności różnych hipotez można sprawdzić, opierając się na wynikach doświadczeń nad zachowaniem się materiałów w prostych i złożonych stanach naprężeń (Zawada 1986). Dlatego wykonano badania rozdrabniania materiału skalnego (wapienia) poprzez ściskanie warstwy ziaren umieszczonych $\mathrm{w}$ cylindrze i dociskanych stemplem prasy hydraulicznej.

Próbom ściskania poddano wapień zwięzły (dewoński), o różnym uziarnieniu. $\mathrm{D}_{80}$ nadawy dla poszczególnych próbek wynosiło: wapień $2 / 8 \mathrm{~mm}-\mathrm{D}_{80}=7,6 \mathrm{~mm}$; wapień $6,3 / 8 \mathrm{~mm}-\mathrm{D}_{80}=8,2 \mathrm{~mm}$; wapień $2 / 20 \mathrm{~mm}-\mathrm{D}_{80}=12,0 \mathrm{~mm}$; wapień $8 / 20 \mathrm{~mm}-\mathrm{D}_{80}=$ $=14,2 \mathrm{~mm}$; wapień $16 / 20 \mathrm{~mm}-\mathrm{D}_{80}=19,2 \mathrm{~mm}$. Badany materiał umieszczono w cylindrze (rys 4b) i obciążano stemplem prasy hydraulicznej. Grubość warstwy ściskanego materiału odpowiadała wielkości szczeliny wylotowej średniej wielkości prasy walcowej, aby warunki ściskania były zbliżone do warunków panujących w warstwie materiału przechodzącej pomiędzy walcami prasy. 


\section{Wyniki badań i dyskusja}

Wyniki badań ściskania próbek wapienia przedstawiono na rysunkach 5, 6, 7 i 8.

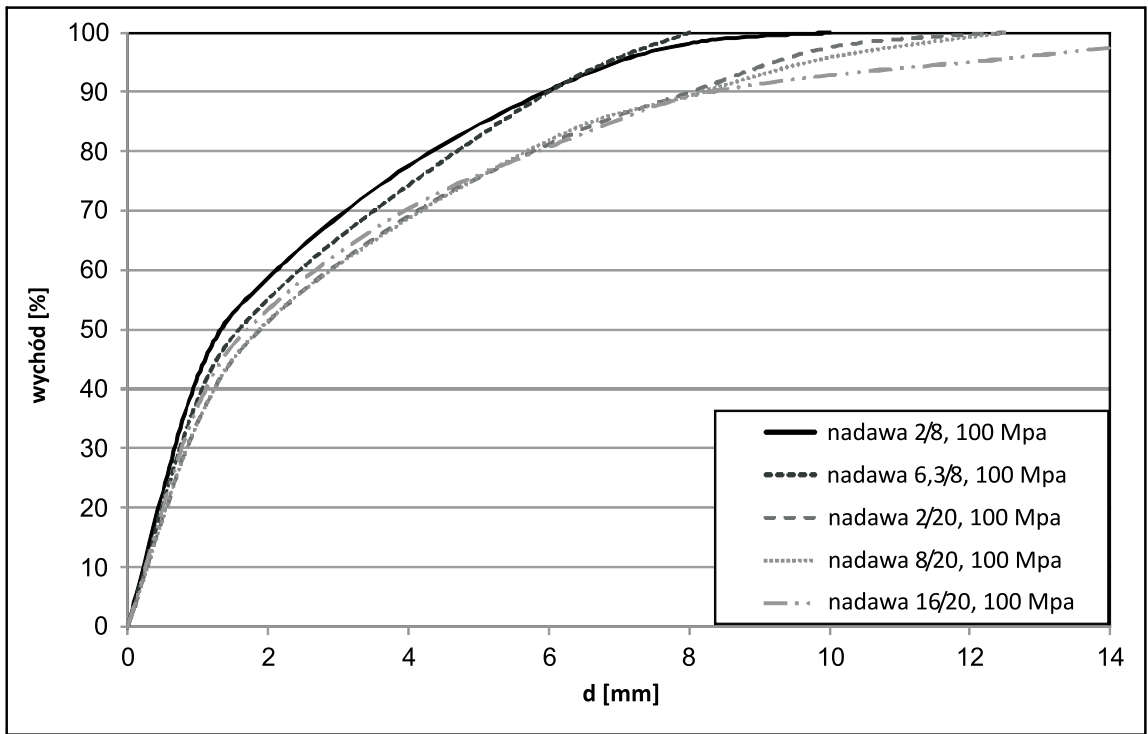

Rys. 5. Skład ziarnowy produktów po ściskaniu na prasie, przy ciśnieniu $100 \mathrm{MPa}$

Fig. 5. Particle size distributions of HPGR products at the pressure $100 \mathrm{MPa}$

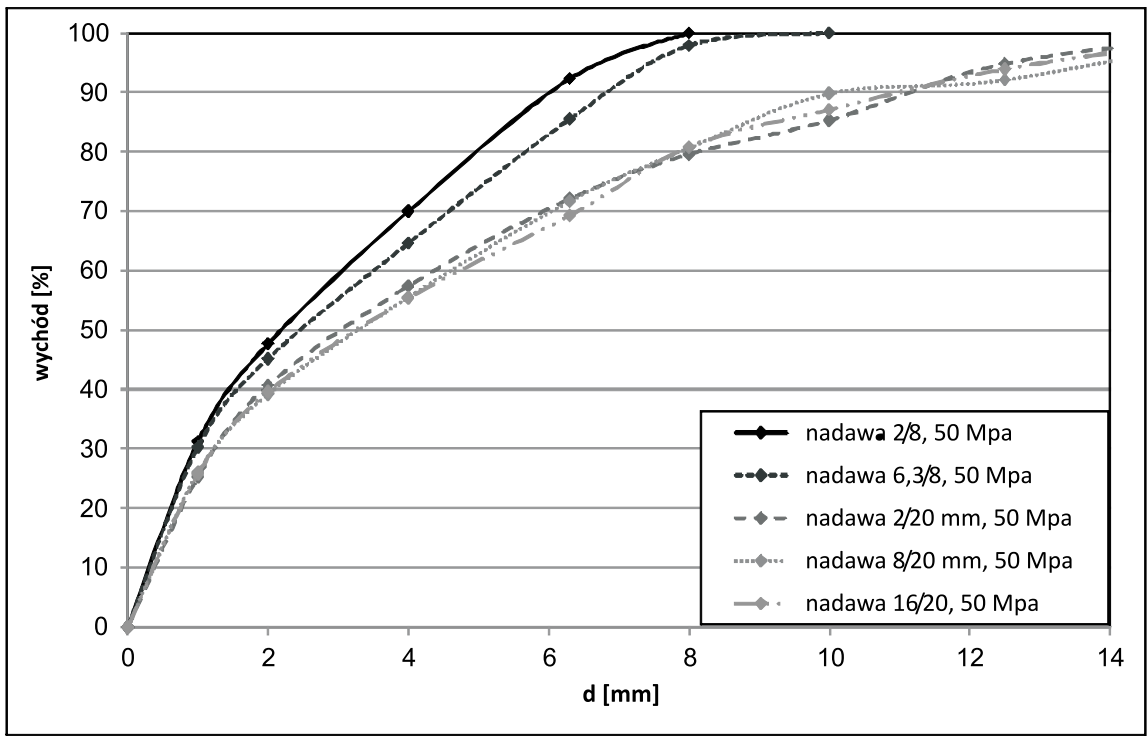

Rys. 6. Skład ziarnowy produktów po ściskaniu na prasie, przy ciśnieniu $50 \mathrm{MPa}$

Fig. 6. Particle size distributions of HPGR products at the pressure $50 \mathrm{MPa}$ 
Analizując wyniki ściskania próbek wapienia na prasie hydraulicznej, należy stwierdzić wyraźny wpływ wywieranego ciśnienia na efekt rozdrabniania. Ilustruje to rysunek 7 , na którym przedstawiono średnie składy ziarnowe wapienia po ściskaniu na prasie przy ciśnieniu 50 i $100 \mathrm{MPa}$. Stopień rozdrobnienia dla poszczególnych próbek wynosił: $\mathrm{i}_{80}=1,9$ - dla ciśnienia $50 \mathrm{MPa}$ oraz $\mathrm{i}_{80}=2,6$ - dla ciśnienia $100 \mathrm{MPa}$. Stopnie rozdrobnienia poszczególnych próbek podano w tabeli 1 . Oprócz wpływu ciśnienia widoczny jest wpływ

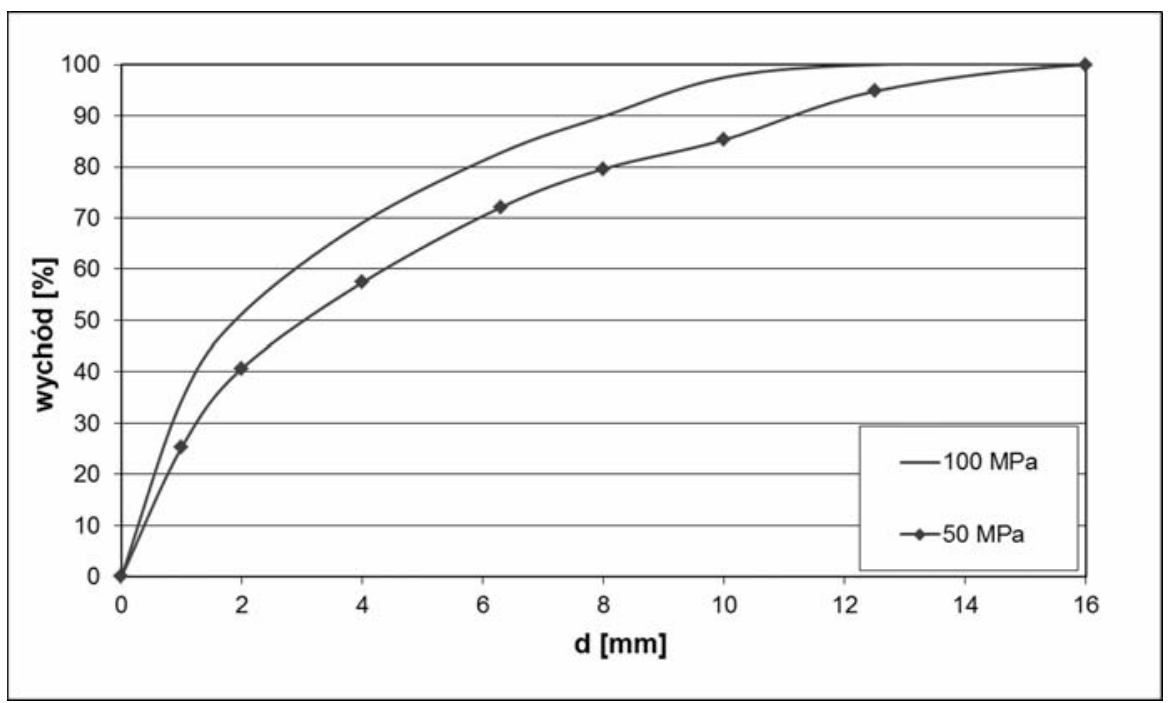

Rys. 7. Średnie składy ziarnowe wapienia po ściskaniu w cylindrze na prasie hydraulicznej przy ciśnieniu 50 i $100 \mathrm{MPa}$

Fig. 7. Average particle size distribution functions of product (limestone) after hydraulic press test for operating pressure 50 and $100 \mathrm{MPa}$

TABELA 1

Efekty rozdrabniania próbek wapienia przez stempel prasy hydraulicznej

Comminution effects for limestone samples in hydraulic press

\begin{tabular}{|c|c|c|c|c|c|c|c|}
\hline \multirow{2}{*}{$\begin{array}{c}\text { Granulacja } \\
\text { nadawy } \\
{[\mathrm{mm}]}\end{array}$} & \multirow{2}{*}{$\begin{array}{c}\text { Jamistość } \\
\text { nadawy } \\
{[\%]}\end{array}$} & \multicolumn{3}{|c|}{ Produkt po ściskaniu, ciśnienie $50 \mathrm{MPa}$} & \multicolumn{3}{|c|}{ Produkt po ściskaniu, ciśnienie $100 \mathrm{MPa}$} \\
\hline & & $\begin{array}{c}\text { stopień } \\
\text { rozdrobnienia } \\
\mathrm{i}_{80} \\
\end{array}$ & $\begin{array}{c}\text { gęstość po } \\
\text { ściskaniu } \\
{\left[\mathrm{Mg} / \mathrm{m}^{3}\right]} \\
\end{array}$ & $\begin{array}{c}\text { zmniejszenie } \\
\text { objętości } \\
{[\%]}\end{array}$ & $\begin{array}{c}\text { stopień } \\
\text { rozdrobnienia } \\
\mathrm{i}_{80} \\
\end{array}$ & $\begin{array}{c}\text { gęstość po } \\
\text { ściskaniu } \\
{\left[\mathrm{Mg} / \mathrm{m}^{3}\right]} \\
\end{array}$ & $\begin{array}{c}\text { zmniejszenie } \\
\text { objętości } \\
{[\%]}\end{array}$ \\
\hline $2 / 8$ & 50,4 & 1,5 & 2,10 & 32 & 1,8 & 2,23 & 37 \\
\hline $6,3 / 8$ & 51,5 & 1,4 & 2,11 & 35 & 1,8 & 2,21 & 38 \\
\hline $2 / 20$ & 48,9 & 1,5 & 2,11 & 28 & 2,1 & 2,24 & 32 \\
\hline $8 / 20$ & 53,0 & 1,8 & 2,09 & 38 & 2,5 & 2,21 & 39 \\
\hline $16 / 20$ & 57,0 & 2,5 & 2,05 & 42 & 3,3 & 2,21 & 44 \\
\hline
\end{tabular}


składu ziarnowego nadawy. Szczególnie istotna jest górna granica uziarnienia ściskanego kruszywa. Dla obydwu wartości ciśnienia ( 50 i $100 \mathrm{MPa}$ ) najmniejszy stopień rozdrobnienia uzyskano dla materiałów drobniejszych. Dla materiału grubego i monofrakcyjnego uzyskano najwyższe stopnie rozdrobnienia, czyli rozdrabnianiu w większym stopniu ulegały grube ziarna nadawy. Materiały o takiej samej górnej granicy uziarnienia, różniące się natomiast zawartością drobnej klasy ziarnowej, po ściskaniu na prasie posiadały prawie identyczny skład ziarnowy. Jest to korzystne, gdyż nie następuje nadmierne przemielanie materiału już rozdrobnionego. Sprzyjać temu może sposób obciążenia ziaren (rys. 4) powodujący, że łatwiej następowało rozdrabnianie ziaren grubych oraz fakt, że przy materiale monofrakcyjnym trudno mówić o złożonym stanie naprężenia, jak to ma miejsce przy materiale polifrakcyjnym, drobnoziarnistym. Wyniki powyższe są zbieżne z wynikami ściskania pojedynczych ziaren (rys. 3), gdzie ziarna drobne charakteryzowały się większą wytrzymałością.

Materiał zawierający ziarna drobne i charakteryzujący się szerokim zakresem uziarnienia trudniej poddawał się rozdrabnianiu, czego powodem może być:

— większa wytrzymałość ziaren drobnych,

— prawie trójosiowy stan naprężenia, czyli wzrost wytrzymałości ziaren poddawanych trójosiowemu obciążeniu.

W omawianym eksperymencie dla materiału monofrakcyjnego uzyskano większe stopnie rozdrobnienia. Jednak stopień rozdrobnienia tylko częściowo opisuje nam efektywność procesu rozdrabniania. Ważna jest również wydajność tego procesu. W warunkach przemysłowych zaobserwowano, że skład ziarnowy nadawy ma wpływ na wydajność pras

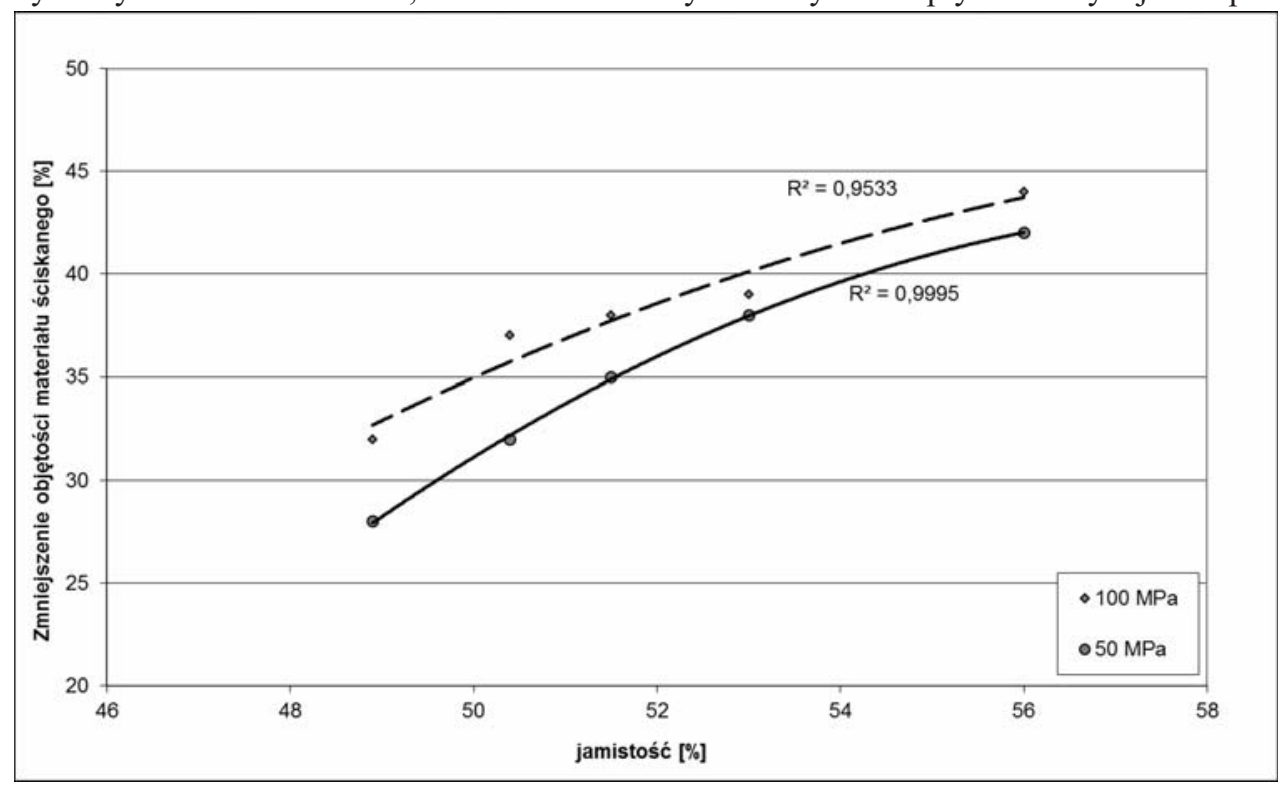

Rys. 8. Zależność zmian objętości ściskanego materiału od jego jamistości

Fig. 8. Relationship between the volume of pressed material and its void content 
walcowych (Nowak 1999). Na rysunku 8 przedstawiono przebieg zmian objętości ściskanych próbek w zależności od początkowej jamistości materiału ściskanego.

Przez jamistość rozumie się objętość przestrzeni pomiędzy ziarnami kruszywa wypełnionych powietrzem. Materiał o większej jamistości (o mniej zróżnicowanym uziarnieniu) ulegał w większym stopniu zmniejszeniu objętości podczas ściskania. Zjawisko to powoduje, że warstwa ściskanego materiału wolniej osiaga stabilizację, a przez to wydajność procesu może być mniejsza. Gęstość materiału kruszonego wynosiła $2,70 \mathrm{Mg} / \mathrm{m}^{3}$. Po ściskaniu materiał osiąnął średnią gęstość nasypową $2,09 \mathrm{Mg} / \mathrm{m}^{3}$, dla ciśnienia $50 \mathrm{MPa}$ i gęstość nasypową $2,22 \mathrm{Mg} / \mathrm{m}^{3}$, dla ciśnienia $100 \mathrm{MPa}$. Stanowi to odpowiednio 77 i $82 \%$ gęstości prasowanej nadawy i odpowiada gęstościom uzyskiwanym w prasach walcowych w warunkach przemysłowych. Widoczny jest niewielki wpływ jamistości nadawy na wartość gęstości materiału po ściskaniu. Dla największej jamistości uzyskano najmniejszą gęstość po ściskaniu. W warunkach przemysłowych, gdzie warstwa materiału przepływa pomiędzy walcami w sposób ciągły, zjawisko to będzie miało większe znaczenie. Dla pras walcowych charakterystyczne jest kruszenie w obiegu zamkniętym, o krotności obiegu $>2$. Warstwa nadawy o mniejszej jamistości (warstwa materiału zawiera drobny materiał z zawrotu i charakteryzuje się większym zróżnicowaniem uziarnienia) szybciej osiaga stabilizację, a przez to zwiększa się wydajność procesu rozdrabniania.

\section{Podsumowanie}

Na ogół przyjmuje się (i potwierdza to praktyka), że skład ziarnowy nadawy nie wpływa na skład ziarnowy produktów po rozdrabnianiu w danym urządzeniu kruszącym. W przeprowadzonych próbach ściskania wapienia umieszczonego w cylindrze, poprzez tłok dociskany stemplem prasy hydraulicznej, uzyskano różne stopnie rozdrobnienia, zależnie od składu ziarnowego nadawy. Również zwiększenie ciśnienia wywieranego przez tłok pozwoliło na zwiększenie stopnia rozdrobnienia. W praktyce podstawowym sposobem wpływania na zwiększenie wychodu materiału drobnego jest zmniejszenie szczeliny wylotowej urządzenia kruszącego. Analizując otrzymane wyniki można stwierdzić, że prasa walcowa posiada duże możliwości regulacji stopnia rozdrobnienia. Możliwa jest bowiem regulacja uziarnienia produktu poprzez regulację wielkości szczeliny pomiędzy walcami, poprzez regulację wielkości wywieranego ciśnienia i poprzez podawanie nadawy o określonym składzie ziarnowym, a tym samym o określonej jamistości. Podawanie materiału o mniejszej jamistości czyli o większym zróżnicowaniu uziarnienia, sprzyja osiągnięciu większego stopnia rozdrobnienia. Zastosowanie większego ciśnienia sprzyja uzyskaniu większego rozdrobnienia, ale może być niekorzystne z powodu większego zużycia materiału, z którego wykonane są bieżnie walców prasy.

Planuje się przeprowadzić próby ściskania kruszywa umieszczonego w cylindrze przy różnych grubościach warstwy. Porównanie efektów rozdrabniania warstwy materiału skalnego przy różnym ciśnieniu i przy różnej jej grubości, z wynikami ściskania pojedynczych 
ziaren, pozwoli na bardziej dokładne ustalenie wpływu różnych parametrów pracy pras walcowych na efektywność rozdrabniania.

Artykuł jest efektem realizacji projektu badawczego Ministerstwa Nauki i Szkolnictwa Wyższego nr NN 524466139

\section{LITERATURA}

Broch E., Franklin J.A., 1972 - The point-load strength test. International Journal of Rock Mechanics and Mining Sciences v. 9, p. 669-697.

Brożek i in. 1995 - Brożek M., Mączka W., Tumidajski T., 1995 - Modele matematyczne procesów rozdrabniania. Rozprawy Monografie nr 35. Wydawnictwa AGH, Kraków.

Brożek M., Oruba-B rożek E., 2003 - Zależność wytrzymałości na rozciąganie ziaren wapienia i porfiru od rodzaju mikroszczelin. Inżynieria Mineralna nr S. 3 (10), s. 200-207.

Brożek i in. 2008 - Brożek M., Oruba-Brożek E., Nowakow ska A., 2008. Wpływ związków powierzchniowo czynnych na rozdrabnianie ziaren dolomitu. Gospodarka Surowcami Mineralnymi t. 25, z. 1 , s. $35-50$

Cottre 11 A.H., 1964 - The mechanical properties of matter. J.Wiley and Sons. New York.

Hoble r M., 1977 - Badania fizykomechanicznych własności skał. PWN, Warszawa.

Majcherczyk T., 1989 - Badanie fizycznych własności skał. Wydawnictwo AGH, Kraków.

N a zi e mi e c Z., S a ra mak D., 2009 - Analiza zmian obciążenia materiału w strefie zgniotu pras walcowych. Zeszyty Naukowe AGH, Górnictwo i Geoinżynieria, t. 33 z. 4, s. 221-234.

N ow a k E., 1999 - Prace Instytutu Mineralnych Materiałów Budowlanych Nr 26, Opole.

Saramak D., 2010 - Analiza powiązań pomiędzy parametrami technologicznymi pras walcowych z wykorzystaniem analizy czynnikowej. Zeszyty Naukowe AGH, Górnictwo i Geoinżynieria, t. 34, z. 4/1, s. $251-263$.

S a r a mak D., 2011a - Technological Issues of High-Pressure Grinding Rolls Operation in Ore Comminution Processes. Archives of Mining Sciences, vol. 56, no 3, s. 517-526.

S a ra mak D., 2011b - Analiza efektywności pracy technologicznych układów rozdrabniania surowców z wysokociśnieniowymi prasami walcowymi. Zeszyty Naukowe Politechniki Śląskiej, Górnictwo i Geologia, t. 6, z. 2, s. 189-200.

Saramak D., 2011c - Podstawowe parametry determinujące proces rozdrabniania w prasach walcowych. Magazyn Autostrady, Budownictwo drogowo-mostowe, nr 10, s. 84-86.

Saramak i in. 2010 - Saramak D., Tumidajski T., Brożek M., Gawenda T., Naziemiec Z., $2010-$ Aspects of comminution flowsheets design in processing of mineral raw materials. Gospodarka Surowcami Mineralnymi, t. 26, z. 4, s. 59-69.

Shipway P.H., Hutching s J.M., 1993 - Fracture of brittle sphere under compression and impact loading II. Results for lead-glass and sapphire spheres. Philosophical Magazine A, t. 67, s. 1405-1421.

Z a w a d a J., 1986 - O problemie określania sił kruszenia. Prace Naukowe Politechniki Warszawskiej. Mechanika, Warszawa. 
Prasy walcowe, rozdrabnianie surowców, ściskanie ziaren skalnych

\section{Streszczenie}

W artykule przeanalizowano opisy procesu rozdrabniania przy użyciu różnych teorii. Scharakteryzowano pokrótce teorię stanów granicznych, teorię sprężystości oraz teorię plastyczności dla wyjaśnienia niektórych efektów obserwowanych w procesie rozdrabniania materiałów kruchych. Bardziej szczegółowo opisano zjawiska występujące przy rozdrabnianiu w wysokociśnieniowych prasach walcowych, przeanalizowano wpływ wybranych czynników na wyniki rozdrabniania. Ocenę przydatności różnych hipotez do interpretacji procesu rozdrabniania w wysokociśnieniowych prasach walcowych przeprowadzono na podstawie badań eksperymentalnych.

Przedstawiono wyniki prób ściskania wapienia w warunkach podobnych do istniejących przy rozdrabnianiu w prasach walcowych. Kruszywo wapienne umieszczone w stalowym cylindrze poddawano ściskaniu poprzez stempel prasy hydraulicznej. Ściskano próbki o różnym uziarnieniu kruszywa i przy różnej wielkości ciśnienia. Oprócz wpływu wielkości ciśnienia prasowania stwierdzono wpływ uziarnienia nadawy na efekt rozdrabniania. Porównanie otrzymanych wyników wskazuje na duże możliwości regulacji parametrów pracy pras walcowych.

\section{ANALYSIS OF THE MECHANICS OF THE COMMINUTION PROCESS OF MINERALS} IN CRUSHERS AND HIGH-PRESSURE GRINDING ROLLS

$$
\text { Key words }
$$

High-pressure grinding rolls, comminution, rock particles pressing

\section{Abstract}

This paper describes comminution processes using the theories of limiting states, elasticity, and plasticity to explain some effects observed in the process of crushing brittle materials. It further describes the phenomena occurring during crushing in high-pressure roll presses and analyzes the effects of selected factors upon crushing results. The evaluation of the usefulness of various hypotheses for interpretation of the crushing process in the high-pressure grinding roll was carried out by means of experimental investigations.

A series of laboratory crushing tests were also conducted in which limestone samples were pressed in a hydraulic piston-die press. Comminution conditions in this press are similar to those observed in the working chamber of HPGR presses. The limestone aggregate, placed in a steel cylinder, was exposed to pressure exerted by the stamp of the press. Samples had various particle size distributions, and experiments were conducted for two values of pressing force. Operating pressure was the main parameter influencing the obtained comminution effects, but the particle size distribution also has an impact on the process effects. A comparison of the results of the investigations indicated that there exists a significant potential for adjusting the operational parameters of high-pressure grinding rolls.

Internal stresses are a derivate of crushing actions such as compression, impact, bending, and shearing. The result of crushing in a particular crusher depends on the strength properties of particles reacting to a specific type of crushing actions. In every crusher there are many crushing actions out of which one is dominating due to the crusher type. Impact is a dominating factor in impact or hummer crushers. Various actions of crusher elements on the crushed material are beneficiary. For example, the shape of the jaw surface in jaw crushers, cone surface in cone crushers, or roll surface in roll presses are important. 
The character and size of deformations depend on the type and magnitude of applied forces (stresses); therefore, the rocks are characterized by a different strength depending on the load applied.

Difficulties in investigations of the strength of brittle materials against direct crushing meant that only approximate methods could be practically used.

The transverse compression of thin plates (rollers) with the load displaced on a small surface is generally known as the Brazilian test. It consists of axial compression of a disk of diameter $d$ and thickness $h$. Tearing stresses appear in the center of the disk, leading to the sample's destruction. The comparison of the disk's strength and the strength of irregular particles compressed between two points proved them to be equal.

A large scatter of results was observed in measurements of the tearing strength of mineral particles. This scatter is caused by the random character of the phenomena occurring during tearing, such as particle shape, arrangement, load conditions, and the internal structure of a given particle. Consequently, the strength of the rock material is characterized by a certain distribution and the crushing process possesses a statistical character.

Increasing a rock's humidity results in a decrease in the rock's strength because water is a surface active compound which decreases the free surface energy. It is very important in the crushing processes of rock materials which are usually carried out under conditions of natural humidity.

High pressure roller presses constitute a contemporary type of roller crushers which are increasingly applied in the crushing processes of minerals. Due to their low energy consumption, they are becoming more popular in ore processing, cement industry applications, and clinker milling. In crushers and roller presses, crushing occurs between two horizontal rolls rotating towards each other. The rollers may have smooth, grooved, or toothed surfaces.

There are different forces acting upon the crushed material between rollers. When both rollers rotate with the same speed, crushing occurs as a result of squeezing (with smooth or grooved rollers) or splitting (with toothed rollers).

The material is transported in the so-called choking system, consisting of mounting the self-dumping tank over the press. The material fills the entire space over the device as well as the working chamber of the press. The material is tightly packed and air voids between particles are significantly reduced in such a way that smaller particles are placed between larger ones.

The crushing process results in the origination of microcracks and microfissures, which enhance further crushing mainly at the third and fourth degree of crushing in ball mills. The obtained energy consumption, measured by Bond's index, is reduced by about $20-30 \%$ in the case of softer limestone, and by $15-20 \%$ for harder materials.

The closed circulation of material is a characteristic feature of roller presses. The multiplication factor of circulation is most often 2 or more. The processing of monodispersive material contributes to obtaining higher rates of comminution (by about 30\%) than in crushing of polydispersive materials, but the press efficiency at crushing the monodispersive material decreases significantly. It is caused by a deterioration of the consolidation and stabilization of the crushed layer. The density rate can be improved by introducing a portion of fine material into the monodispersive material. Fine particles filling the voids between coarse particles are characterized by higher strength.

Experimental tests were carried out to evaluate the above hypotheses of crushing in high-pressure roller presses. The crushing tests on a rock material (limestone) were performed by means of compressing the layer of particles in the cylinder and pressing with the hydraulic press punch. Compression tests were applied to compact (Devon) limestone of different particle size distributions. The tested material was placed in the cylinder and loaded with the press punch. The thickness of the compressed material corresponded to the size of an outlet port on an average roller press to make the compression conditions close to those in the material layer between the rollers.

Analyzing the results of the compression of limestone samples in the hydraulic press, it is possible to observe an influence of applied pressure upon the effect of crushing (Fig. 7). The comminution rates of respective samples are given in Table 1. Apart from the pressure effect, there is also an influence from the feed particle composition. For coarse and mono-fraction material, the highest rates of particle size distribution were achieved, i.e. coarse particles of the feed were subject to crushing in a higher degree. The materials of the same upper boundary of particle size distribution, differing by the content of fine particle class, had an almost identical particle composition after compressing. This is advantageous since overmilling of the already crushed material does not occur.

It can be stated while analyzing the obtained results, that the roller press has great potential for regulating the particle size distribution. It is possible to regulate the product particle size by means of regulating the gap between rollers, by regulating the exerted pressure, and by delivering the feed of the given particle size distribution, i.e. of the determined cavity rate. 
